Abstracta Iranica Abstracta Iranica

Revue bibliographique pour le domaine irano-aryen

Volume 28 | 2007

Comptes rendus des publications de 2005

\title{
«The shape of sherds: function and style at Godin II ». IA, 40, 2005, pp. 249-269.
}

\section{Rémy Boucharlat}

\section{(2) OpenEdition}

1 Journals

\section{Édition électronique}

URL : http://journals.openedition.org/abstractairanica/15782

DOI : 10.4000/abstractairanica.15782

ISSN : 1961-960X

Éditeur:

CNRS (UMR 7528 Mondes iraniens et indiens), Éditions de l'IFRI

\section{Édition imprimée}

Date de publication : 15 mai 2007

ISSN : 0240-8910

\section{Référence électronique}

Rémy Boucharlat, « "The shape of sherds: function and style at Godin II ». IA, 40, 2005, pp. 249-269. », Abstracta Iranica [En ligne], Volume 28 | 2007, document 87, mis en ligne le 18 septembre 2007,

consulté le 25 septembre 2020. URL : http://journals.openedition.org/abstractairanica/15782 ; DOI : https://doi.org/10.4000/abstractairanica.15782

Ce document a été généré automatiquement le 25 septembre 2020.

Tous droits réservés 


\title{
« The shape of sherds: function and style at Godin II ». IA, 40, 2005, pp. 249-269.
}

\author{
Rémy Boucharlat
}

Dans un précédent article (Abs. Ir. 26, c.r. n 102), H.G. discutait la chronologie interne de la période II de Godin Tepe près de Kangāvar, par le jeu des comparaisons de la céramique : entre 650 et 550 pour l'occupation principale (qui se divise en Early and Late phases) et autour de 500 pour la période «squatter ». Ici, elle s'attache aux formes et fonctions des collections des deux phases, sans oublier qu'il s'agit dans tous les cas de tessons rejetés sur des sols extérieurs ou bien de poubelles. Pour la période de réoccupation modeste, on observe, entre autres et sans surprise, une standardisation des formes et une proportion moindre de céramiques fines.

\section{INDEX}

Thèmes : 3.2.2. Pré-Achéménides et Achéménides

\section{AUTEURS}

RÉMY BOUCHARLAT

IFRI / CNRS - Téhéran / Lyon 